\title{
Magdalena Dąbrowska
}

Uniwersytet Warszawski

m.dabrowska@uw.edu.pl

\section{Ziemie polskie połowy XIX wieku oczyma Rosjan \\ (Piotr Dubrowski i Michaił Glinka)}

Artykuł zawiera omówienie wspomnień P. I. Dubrowskiego o M. I. Glince („Russkij wiestnik"1857) oraz Opisu Warszawy i jej okolic... (Warszawa 1850; z opisem Częstochowy oraz indeksem ulic i mapą Warszawy) P. I. Dubrowskiego. Dubrowski i Glinka przebywali na ziemiach polskich w latach czterdziestych i pięćdziesiątych. XIX wieku. Piotr Dubrowski (1812-1882) - autor pierwszej książki o Adamie Mickiewiczu, literaturoznawca i językoznawca, tłumacz, wydawca czasopisma „Jutrzenka. Diennica” w języku rosyjskim i polskim. Michaił Glinka (1804-1857) - kompozytor, twórca oper Iwan Susanin i Rusłan i Ludmiła; w Warszawie skomponował scherzo orkiestrowe Kamarinskaja (1848).

Słowa kluczowe: Piotr Dubrowski, Michaił Glinka, wspomnienia, Warszawa, kontakty

...mnie również los rzucit $w$ inny, daleki kraj.

Piotr Dubrowski ${ }^{1}$

${ }^{1}$ П. Дубровский, Воспоминания о М.И. Глинке. Письмо к Л.И. Шестаковой, „Русский вестник”, 8(2)/1857, с. 572. Por.: Глинка в воспоминаниях современников, ред. А. А. Орлова, Москва 1955. Tu i dalej, о ile nie podano inaczej, przekład własny - M.D. 


\section{Uwagi wstępne}

Po latach badań nad społecznością polską w Rosji, które zaowocowały powstaniem zarysów dziejów obecności Polaków w poszczególnych miastach czy regionach ${ }^{2}$, słowników biograficznych (lub biobibliograficznych $)^{3}$ oraz szczegółowych opracowań życia i działalności konkretnych osób ${ }^{4}$, nadszedł czas na intensyfikację studiów nad społecznością rosyjską na ziemiach polskich XIX wieku. Stanisław Wiech i Jacek Legieć w przedmowie do słownika rosyjskich mieszkańców Królestwa Polskiego, będącego jednym z najnowszych (z 2015 roku) świadectw natężenia badań nad drugą kwestią, tłumaczą dysproporcję między poziomem zaawansowania studiów nad obydwoma problemami - wyeksponowaniem pierwszego i zaniedbaniami w zakresie drugiego - „wybitnie narodowym i egocentrycznym charakterem” obrazu ziem polskich czasów rozbiorów w polskiej historiografii oraz myśli historycznej, „typowym niemal dla wszystkich historiografii narodowych spłaszczeniem panoramicznego spojrzenia na przeszłość"s. Droga do uzyskania wielowymiarowego obrazu danego wycinka przeszłości prowadzi przez uwzględnienie i obiektywną ocenę opinii reprezentantów różnych narodowości. Jak zauważyli wspomniani badacze, „z tej perspektywy można dostrzec nie tylko nowe, zazwyczaj pomijane lub tylko marginalnie traktowane w polskiej historiografii zjawiska i cechy, lecz także lepiej poznać i zrozumieć mechanizmy własnego zachowania czy też określić charakter i nastawienie opisu-

${ }^{2}$ Np. L. Bazylow, Polacy w Petersburgu, Wrocław-Warszawa-Kraków-GdańskŁódź 1984.

${ }^{3}$ Np. A. Kijas, Polacy w Rosji od XVII wieku do 1917 roku. Stownik biograficzny, Warszawa-Poznań 2000.

${ }^{4} \mathrm{~Np}$. П. Глушковский, Ф.В. Булгарин в русско-польских отношениях первой половинь XIX века: эволючия идентичности и политических воззрений, СанктПетербург 2013.

${ }^{5}$ S. Wiech, J. Legieć, Królestwo Polskie i jego mieszkańcy w świetle rosyjskich wspomnień, pamiętników, relacji i dzienników. Zbiór bibliograficzny, Kielce 2015, s. 7 . 
jących nas sąsiadów"6. Zasadne wydaje się w tym kontekście przypomnienie klasycznej już definicji dialogu kultur, zaproponowanej przez Rocha Sulimę. Opiera się on na „uznaniu różnic kulturowych, odmienności kultur”, czyni „te kultury równorzędnymi partnerami” i podsuwa „ich nosicielom wizje nowych powiązań i nowych sprzeczności, realizujących się w ramach nadrzędnych całości, [...] kultury - mówiąc umownie - światowej”; jego nawiązanie przynosi pożytek wszystkim stronom, gdyż wraz z rozszerzającym się zakresem poznania pogłębia się znajomość każdej z nich: ,jedna kultura nie może «poznać siebie», nie może zdobyć świadomości siebie bez rozpoznania się, «przejrzenia się» w lustrze innej kultury"

Na pierwszy rzut oka Piotra Pawłowicza Dubrowskiego (18121882), slawistę, lingwistę i literaturoznawcę, autora pierwszej książki o Adamie Mickiewiczu, publicystę i thumacza, oraz Michaiła Iwanowicza Glinkę (1804-1857), kompozytora, twórcę oper Życie za cara (Iwan Susanin) oraz Rustan i Ludmita, muzyki symfonicznej i kameralnej, romansów i pieśni, łączy tylko to, że obaj przez pewien czas przebywali na ziemiach polskich. Glinka gościł w Warszawie na przełomie lat czterdziestych i pięćdziesiątych. Pozostawał w kręgu Karola Kurpińskiego i Karola Lipińskiego. Tu też skomponował scherzo orkiestrowe Kamarinskaja i swoje najdoskonalsze pieśni, w tym Pieśń Margarity zainspirowaną Faustem Goethego. Kilka pobytów Glinki w Warszawie (marzec - listopad 1848 roku, maj 1849 - wrzesień 1851, maj 1854 i 1856) przypadło na ostatni okres jego życia i twórczości, obejmujący lata 1844-1857 ${ }^{8}$. W biografii Dubrowskiego można wyróżnić cztery okresy (przed 1837 rokiem, 1837-1851, 1851-1862, 1862-1882), przy czym z pobytem na ziemiach polskich związany był okres drugi oraz trzeci. W latach 1837-1851 Dubrowski pracował jako nauczyciel języka rosyj-

${ }^{6}$ Tamże.

${ }^{7}$ R. Sulima, Literatura a dialog kultur, Warszawa 1982, s. 174.

${ }^{8}$ Zob.: A. Neuer, Glinka, [w:] Encyklopedia muzyczna PWN, t. 3, Kraków 1987, s. 323 . 
skiego w Łowiczu i Warszawie oraz jako warszawski cenzor, w latach 1862-1882 przebywał na ziemiach polskich jako członek-korespondent Rosyjskiej Akademii Nauk, mieszkając w Warszawie i Skierniewicach ${ }^{9}$. Dlaczego jednakże akurat Dubrowski i Glinka są wymieniani obok siebie, skoro osób w podobnej sytuacji - czyli zasłużonych dla kultury Rosjan przebywających na ziemiach polskich w połowie XIX stulecia można wymienić znacznie więcej? Nie daje odpowiedzi na to pytanie nawet informacja, że obu łączyły z Polską głębsze więzi. Wspomina się o polskim pochodzeniu rodu Glinków, którego innym wybitnym przedstawicielem był wydawca czasopisma „Russkij wiestnik” z lat 1808-1820 i 1824, Siergiej Glinka. Jego wypowiedź o polskich korzeniach skomentował Ludwik Bazylow: „widać [...] wyraźnie, że [...] dawne polskie pochodzenie sprawiało rzeczywiście przyjemność, choć możliwe jest też, że czasami zachowały się jednocześnie i sympatie do Polski; na szczególną uwagę zasługuje fakt, że chodzi o Smoleńszczyznę [miejsce urodzenia zarówno Siergieja, jak i Michaiła Glinków M.D.], która należała do Polski w latach 1611-1654: królowie polscy poczynili tam wtedy szereg nadań, a gdy rejon ten powrócił do Rosji, nadania mogły zostać potwierdzone lub nie, [...] pochodzenie polskie miało w takich sytuacjach dużą wage" "10. Dubrowski zapisał się zaś jako propagator ,,idei słowiańskiej oraz polsko-rosyjskich związków literackich”", którego czasopismo „Jutrzenka. Diennica”, wydawane w języku polskim i rosyjskim w Warszawie w latach 1842-1843, miało być „uniwersalnym ogólnosłowiańskim organem prasowym, upowszechniającym idee braterstwa Słowian i ułatwiającym wymianę kulturalną

${ }^{9}$ Zob.: А. И. Рейтблат, Дубровский Петр Павлович, [в:] П. А. Николаев (ред.), Русские писатели 1800-1917. Биографический словарь, т. 2 (Г-К), Москва 1992, c. 192.

${ }^{10}$ L. Bazylow, Społeczeństwo rosyjskie w pierwszej połowie XIX wieku, WrocławWarszawa-Kraków-Gdańsk 1973, s. 26.

${ }^{11}$ E. Kucharska, Działalność slawistyczna Piotra Dubrowskiego w świetle listów do Izmaiła Sriezniewskiego, Wrocław 1974, s. 5. 
między narodami słowiańskimi”'12. Obecność obu w jednym artykule uzasadnia fakt, iż to właśnie Piotr Dubrowski jest autorem wspomnień o pobycie na ziemiach polskich Glinki, opublikowanych w czasopiśmie „Russkij wiestnik” w 1857 roku (innym piśmie wydawanym pod tym samym tytułem co periodyk Siergieja Glinki), jednym z wielu rosyjskich czasopism, z którymi ściśle współpracował ${ }^{13}$. O ile we wspomnieniach Dubrowski opisał Warszawę i okolice oczyma Glinki i przez pryzmat jego osoby, o tyle w Opisie Warszawy i jej okolic z dotaczonym opisem Częstochowy, wydanym siedem lat wcześniej w Warszawie, stworzył własną - choć wyrastającą z polskich „książek o mieście” - wizję przeszłości i współczesności Warszawy oraz Częstochowy ${ }^{14}$. Obie pozycje staną się przedmiotem analizy w niniejszym artykule, wpisującym się w nurt badań nad utrwalonym w rosyjskich przekazach dokumentalnych XIX wieku obrazie ziem polskich.

\section{Dubrowski o pobycie na ziemiach polskich Michaiła Glinki}

Wspomnienia Dubrowskiego o Glince, opatrzone dopiskiem „Sankt-Petersburg, 12 kwietnia 1857 roku" ${ }^{15}$, a zatem napisane już po śmierci kompozytora (zmarłego 3 (15) lutego tego roku), mają postać - zgodnie z podtytułem - listu do siostry Glinki, Ludmiły Szestakowej, będącego odpowiedzią na jej prośbę o relację z pobytu brata w Warszawie. Bezpośredni zwrot do Szestakowej otwiera i zamyka wspomnienia, tworząc

${ }^{12}$ B. Mucha, ,Jutrzenka” 1842-1843, [w:] B. Galster, J. Kamionka-Straszakowa, K. Sierocka przy współudziale A. Piorunowej (red.), Zwierciadło prasy. Czasopisma polskie XIX wieku o literaturze rosyjskiej, Wrocław-Warszawa-Kraków-Gdańsk 1978, s. 134.

${ }^{13}$ Zob.: П. Дубровский, Воспоминания о М.И. Глинке..., с. 571-580.

${ }^{14}$ [П.П. Дубровский], Описание Варшавы и ее окрестностей с дополнением описания Ченстоховы. Составил П.Д. (С новейшим планом Варшавы). Варшава 1850. Na stronie tytułowej widnieje ,instytucja sprawcza”: „Издание В. М. Истомина, комиссионера Варшавского Учебного Округа".

${ }^{15}$ П. Дубровский, Воспоминания о М.И. Глинке..., с. 580. 
ich ramę kompozycyjną. Symboliczny wydźwięk ma końcowy fragment, gdy Dubrowski odtwarza w pamięci ostatnie spotkanie z twórcą Życia za cara obok mostu na prawym brzegu Wisły: kompozytor obiecywał sobie wtedy, że nie przekroczy linii rzeki w kierunku zachodnim, niedaleka przyszłość pokazała jednak, że stało się inaczej (umarł w Berlinie). Autor wspomnień nie podjął się szerszego nakreślenia życia Glinki, wiedząc, że do opublikowania jego biografii na łamach pisma „Russkij wiestnik” przygotowuje się Władimir Stasow, znany krytyk muzyczny i historyk sztuki ${ }^{16}$.

Dubrowski prezentuje Glinkę jako romantycznego, podatnego na wzruszenia artystę, w pełni sił twórczych, otwartego na rozmaite źródła inspiracji i twórczo je wykorzystującego. Świeże były więc jeszcze jego wrażenia z pobytu w Hiszpanii, skąd wraz z kompozytorem przyjechał do Warszawy Don Pedro, towarzyszący mu w muzykowaniu, a już zaczęły rodzić się wrażenia z obcowania z kulturą polską ${ }^{17}$. Ze wspomnień Dubrowskiego wynika, że nie tylko towarzyszył on Glince w czasie spotkań towarzyskich czy wycieczek do Bielan (wówczas podwarszawskich), ale pośredniczył też $\mathrm{w}$ jego kontaktach z polską kulturą, jako

\footnotetext{
${ }^{16}$ Zob. przypis do wspomnień (tamże, c. 577).

${ }^{17}$ Zob.: H. Swolkień, Michat Glinka, Warszawa 1984. s. 233-245. Por. słowa Aleksandra Lipatowa o rosyjskiej recepcji dzieł Glinki zawierających polskie motywy, rozpatrującego ją w kontekście zacierania się ,rozgraniczenia społeczeństwa obywatelskiego i upaństwowionego”: „Przykładem jest pierwsza rosyjska opera romantyczna o wyraźnym oficjalno-patriotycznym ukierunkowaniu, którego odzwierciedleniem był już sam tytuł - Życie za cara (1836) Glinki. W ciągu oto już ponad półtora wieku olśniona sala po podniesieniu kurtyny żywiołowo wybucha oklaskami na widok «aktu polskiego» - polskich szat narodowych, szlacheckich postur i towarzyszących temu barwnemu widowisku dźwięków mazura. Widoczne piękno polskości tłumi świadomość tego, że zachwyca się wrogami, którzy za chwilę zabiją legendarnego bohatera rosyjskiego. Tak w wieku XIX - wkrótce po zdławieniu powstania listopadowego powtarza się sytuacja znana z wydarzeń wieku XVII: ze strony twórców widowiska fascynacja artystyczną kulturą wrogów, zaś fascynacja obyczajowością polską - ze strony widowni. I znów, jak dwieście lat temu, Muzy okazują się silniejsze od Marsa"; A. Lipatow, Europeizm: punkt wyjścia w poszukiwaniu porozumienia Polaków i Rosjan, [w:] M. Dąbrowska i P. Głuszkowski (red.), Nauka w Polsce i Rosji-miejsca wspólne, miejsca różne (obszar humanistyki), Warszawa 2016, s. 101.
} 
thumacz wierszy Adama Mickiewicza. W Warszawie Glinka skomponował pieśn Rozmowa do oryginalnego tekstu Mickiewicza ${ }^{18}$, dedykując ją Emilii Ohm, swojej nauczycielce języka polskiego i zarazem uczennicy śpiewu i gry na fortepianie. „To pierwszy i jedyny romans napisany przez niego do polskich słów" - czytamy we wspomnieniach ${ }^{19}$. Dubrowski relacjonuje równolegle rozwój kontaktów Glinki z Polakami i rodakami (Iwan Paskiewicz) oraz etapy powstawania poszczególnych dzieł muzycznych (Kamarinskaja, Pieśń Margarity, Zalew Fiński i in.) ${ }^{20} . \mathrm{Z}$ jego słów wyłania się obraz Warszawy jako miejsca, w którym Glinkę wręcz „otaczały” dźwięki, od treli słowików, które słyszał przez okno domu przy ulicy Rymarskiej, aż do odgłosów konduktu pogrzebowego.

Oprócz wspomnień Dubrowskiego i zapowiedzianej przezeń biografii Stasowa na życie Glinki rzuca światło jego autobiografia, w swoich „warszawskich” partiach stanowiąca uzupełnienie wspomnień wydawcy „Jutrzenki”21. Zapiski biograficzne kompozytora dzielą się na cztery części, opatrzone nagłówkami: „od 20 maja 1804 do 25 kwietnia 1830 roku”, „od 25 kwietnia 1830 do końca listopada i początku grudnia 1836 roku”, „od grudnia 1836 do czerwca 1844 roku” oraz „od czerwca 1844 do maja 1854 roku”. Partie „warszawskie” pojawiają się w dwóch rozdziałach części ostatniej, gdzie otrzymują nazwy „pobyt w Warszawie” i „drugi pobyt w Warszawie", choć pierwsza wzmianka o sześciodniowym pobycie tu w towarzystwie Nikołaja Nowosielskiego, działacza ekonomicznego i miłośnika muzyki, pojawia się już we wcześniejszym rozdziale, dotyczącym wyjazdu do Hiszpanii i powrotu do Rosji. Następny pobyt w Warszawie miał się stać dla Glinki oderwaniem od życia w posiadłości

${ }^{18}$ Zob.: I. Bełza, Z dziejów polsko-rosyjskich kontaktów muzycznych, thum. S. Prus-Więckowski, E. Dziębowska, Kraków 1963, s. 122-134 (rozdział Mickiewicz a muzyka rosyjska).

${ }^{19}$ П. Дубровский, Воспоминания о М.И. Глинке.., с. 576. Warto przypomnieć, że wtedy miał już „w tece kompozytorskiej Moja pieszczotke [...] do wiersza Mickiewicza w rosyjskim przekładzie S. Golicyna (1843)"; A. Neuer, Glinka ..., s. 323.

${ }^{20}$ I. Bełza, $Z$ dziejów polsko-rosyjskich kontaktów..., s. 106-121 (rozdział Glinka a polska kultura muzyczna).

${ }^{21}$ Zob.: М.И. Глинка, Записки, ред. А.С. Розанов, Москва 1988. 
Nowospasskoje, gdzie męczyło go ciągłe bawienie gości śpiewem i grą na fortepianie. Tak oto Glinka „wprowadza” do swoich zapisków postać Dubrowskiego: „Wiersze do tych romansów [Aleksandra Puszkina, Michaiła Lermontowa, Johanna Wolfganga Goethego - M. D.] podsunął mi pełniący podówczas obowiązki cenzora w Warszawie P. P. Dubrowski. Poznałem go jeszcze w 1847 roku, kiedy bawiłem przejazdem w Warszawie. W 1848 roku stale odwiedzał mnie i z wrodzoną sobie uczynnością towarzyszył mi często w przechadzkach, bardzo często czytał mi i przeczytaliśmy wspólnie wielu rosyjskich pisarzy oraz innych autorów, w szczególności Szekspira"22. Wzmianki o Dubrowskim pojawią się w zapiskach kompozytora jeszcze dwukrotnie, przy czym po raz drugi w kontekście pobytu w Petersburgu, kiedy ten pełnił obowiązki profesora języka polskiego w Instytucie Pedagogicznym. Wspomnienia Dubrowskiego o Glince oraz zapiski biograficzne samego Glinki w ogólnych zarysach pokrywają się w warstwie faktograficznej, różniąc się - na korzyść autobiografii kompozytora - stopniem szczegółowości. W obu pozycjach odtworzona zostaje topografia Warszawy (Glinka wspomina nie tylko o ulicy Rymarskiej, ale także Długiej, Niecałej i Nalewki ${ }^{23}$ ), mowa jest o obiedzie i koncercie w domu Iwana Paskiewicza, podczas którego wykonano chór z Ifigenii w Taurydzie Christopha Willibalda Glucka, od tej chwili jednego z ulubionych kompozytorów Glinki, pojawiają się wzmianki o Emilii Ohm, przywołany jest epizod ze słowikami na ulicy Rymarskiej (Glinka wymienia jeszcze dwa inne gatunki ptaków) itd. Przykłady można mnożyć. Obydwaj autorzy wprowadzają pojedyncze słowa polskie: „słowiki” (Dubrowski) i „rozmowa” (Glinka). W zapiskach kompozytora pojawia się wzmianka o Stasowie, nazwanym przezeń ,,solidnym muzykiem, miłośnikiem sztuk pięknych i dobrze wykształconym człowiekiem"24.

${ }^{22}$ Tamże, c. 132-133.

${ }^{23} \mathrm{~W}$ 150. rocznicę urodzin Glinki na fasadzie domu przy ul. Niecałej 2 została odsłonięta tablica upamiętniająca kompozytora. Zob.: G. Wiśniewski, Między Rosja i Polska-Igor i Swiatosław Betzowie, Warszawa-Pułtusk 2016, s. 96.

${ }^{24}$ М.И. Глинка, Записки..., с. 134. 


\section{Dubrowski o Warszawie i Częstochowie}

Zasadniczy zrąb Opisu Warszawy i jej okolic z dołaczonym opisem Częstochowy stanowi, zgodnie z tytułem, opis Warszawy, podzielony na trzy rozdziały, poprzedzone opatrzoną dopiskiem „Warszawa, 7 (19) lutego 1850 r." przedmową autorską oraz uzupełnione Alfabetycznym spisem ulic warszawskich i numeracji domów znajdujacych się na nich i Numeracja domów wedlug porządku ich położenia z wykazem ulic, na których sie znajduja. W przedmowie Dubrowski wymienia prace, które wykorzystał przy opracowaniu opisu Warszawy: Rys historyczno-statystyczny wzrostu i stanu miasta Warszawy od najdawniejszych czasów aż do 1847 roku Franciszka Maksymiliana Sobieszczańskiego z 1848 roku, Opisanie historyczno-statystyczne miasta Warszawy Łukasza Gołębiowskiego w drugim (poprawionym i rozszerzonym) wydaniu z 1827 roku $^{25}$, pierwszy tom Starożytnej Polski pod względem historycznym, jeograficznym i statystycznym opisanej... Michała Balińskiego i Tymoteusza Lipińskiego z 1843 roku, pierwszy tom Starożytności Warszawskich: dzieła zbiorowo-zeszytowego Aleksandra Wejnerta z 1848 roku $^{26}$. Za podstawowe źródło autor uznaje dzieło Sobieszczańskiego, historyka, cenzora, którego Wiadomości historyczne o sztukach pięknych $w$ dawnej Polsce (1847-1849) uchodzą za pierwszą syntezę historii sztuki polskiej. Również autorzy pozostałych prac wnieśli duży wkład w rozwój nauki. Gołębiowski - historyk i bibliotekarz - pracował w Towarzystwie do Ksiąg Elementarnych, był sekretarzem Towarzystwa Przyjaciół Nauk, profesorem literatury w Instytucie Pedagogicznym oraz bibliotekarzem Biblioteki Publicznej w Warszawie. Sześciotomowe Starożytności Warszawskie... to najważniejsza praca Wejnerta,

${ }^{25}$ Wydanie pierwsze ukazało się w 1826 roku (jako „,nowy kalendarzyk polityczny na r. 1826”). Zob.: Bibliografia literatury polskiej. Nowy Korbut, t. 4 (Oświecenie), red. E. Aleksandrowska, Warszawa 1966, s. 479.

${ }^{26}$ Zob.: [П.П. Дубровский], Описание Bapmaвbl..., c. nlb. (przedmowa). Zapewne przez analogię do tytułu Starożytności Warszawskie dzieło Balińskiego i Lipińskiego Dubrowski nazywa Starożytnościami Polskimi. 
historyka, varsavianisty, honorowego konserwatora akt miasta Warszawy. Balińskiemu - historykowi, pisarzowi, publicyście, działaczowi oświatowemu - zawdzięczają powstanie w Starożytnej Polsce... ustępy dotyczące ziem litewskich; Lipiński zapisał się jako historyk starożytnik i archeolog. W kontekście dołączonego do omawianej pracy Dubrowskiego opisu Częstochowy, w którym jedno z głównych miejsc zajmują dzieje świętego obrazu, warto przypomnieć, że spod ręki Lipińskiego wyszły w 1850 roku Wiadomości historyczne, numizmatyczne, o koronacjach obrazów Matki Boskiej w dawnej Polsce. O ile dzieła Sobieszczańskiego, Gołębiowskiego, Balińskiego i Lipińskiego oraz Wejnerta były przeznaczone dla polskiego odbiorcy, o tyle Opis Warszawy i jej okolic z dołaczonym opisem Czestochowy Dubrowskiego powstał z myślą o czytelnikach rosyjskich, niewładających językiem polskim w stopniu wystarczającym do zapoznania się z ,oryginałami”. Ma on bowiem charakter kompilacyjny i referujący, na co wskazuje autor nie tylko w przedmowie, ale także w rozdziale pierwszym, kiedy zaznacza, że „objętość i przeznaczenie [...] książki nie pozwalają na przedstawienie szczegółów historyczno-statystycznych na temat Warszawy”27. „Występując wśród Polaków jako stały informator o zagadnieniach literatury polskiej, [Dubrowski - M. D.] wysyłał jednocześnie korespondencje do Rosji na temat życia literackiego Polski” - pisał Marian Jakóbiec ${ }^{28}$, którego słowa - wskazujące na „dwukierunkowość” działalności Dubrowskiego, propagatora kultury polskiej wśród Rosjan i rosyjskiej w kręgu Polaków - można rozwinąć, dodając, że życie literackie nie stanowiło jedynego obiektu jego zainteresowania.

Pierwszy rozdział „opisu Warszawy” opiera się na wyodrębnieniu w dziejach miasta trzech okresów: od założenia do 1596 roku, od 1596 do 1794 roku oraz od początku XIX wieku do współczesności. Drugi za-

${ }^{27}$ Tamże, c. 47.

${ }^{28}$ M. Jakóbiec, Kluczowe problemy stosunków literackich polsko-rosyjskich $w$ latach trzydziestych - czterdziestych wieku XIX, [w:] S. Fiszman (red.), Z polskich studiów slawistycznych. Prace historycznoliterackie na IV Międzynarodowy Kongres Slawistów w Moskwie 1958, Warszawa 1958, s. 135. 
wiera opis ważniejszych miejsc w Warszawie z podziałem na świątynie (prawosławne, rzymsko-katolickie, innych wyznań) oraz ,pałace i inne znaczące gmachy" (pałac w Łazienkach, Belweder, Zamek Królewski, Pałac Kazimierzowski, ogród botaniczny, pomniki i in.) z wyodrębnioną częścią poświęconą Pradze. Rozdział trzeci zawiera przegląd okolic Warszawy. W rozdziale pierwszym, zatytułowanym Historyczno-statystyczne spojrzenie na Warszawe - Dubrowski przestrzega porządku chronologicznego opisywanych wydarzeń (z wyeksponowaniem przeniesienia stolicy z Krakowa oraz utraty przez Polskę niepodległości), w drugim dokonuje hierarchizacji miejsc i obiektów (od najważniejszych do drugorzędnych), w trzecim kieruje się porządkiem geograficznym (od południowych obrzeży miasta do północnych z ponownym wyodrębnieniem strony praskiej). W rozdziale pierwszym zacytowane słowa o niemożności przekazania wszystkich szczegółów na temat Warszawy oddzielają część „historyczną” od „statystycznej”, wypełnionej danymi - według stanu na rok 1849 (czyli poprzedzający wydanie książki) - dotyczącymi położenia geograficznego miasta, liczby ludności z podziałem na przedstawicieli poszczególnych stanów, zawodów oraz wyznań, zabudowy w jej różnych kategoriach (domy, kościoły, klasztory i in.) itd. Są więc podstawy, aby Opis Warszawy... Dubrowskiego rozpatrywać wśród innych - powstających od XVIII wieku - tzw. książek o mieście. Do grupy tej należały przewodniki, informatory oraz książki adresowe ${ }^{29}$, nastawione na dostarczenie wiarygodnej i w miarę możliwości wyczerpującej informacji ${ }^{30}$. Na połowę XIX stulecia przypadły dalsze etapy rozwoju statystyki oraz kartografii, nie wspominając o badaniach z zakresu historii i nauk pomocniczych. Zaopatrzeniu czytelników w dodatkowe wiadomości służyły w pracy Dubrowskiego również przypisy (sześć do opisu Warszawy i jeden do opisu Częstochowy oraz jeden do zamykającego

${ }^{29} \mathrm{~W}$ opisie dzieła Dubrowskiego w bibliotece cyfrowej Polona znajdujemy jego kwalifikację jako ,przewodnik turystyczny”. Zob.: https://polona.pl/item/484160/3/.

${ }^{30}$ Por.: А. Е. Лихобабенко, Путеводители по Москве как тип справочного издания, [w:] М. М. Панфилов (ред.), Русская печать XIX-XX веков. Сборник статей, Москва 1994, с. 53-73. 
całość Alfabetycznego wykazu nazwisk i rzeczy wymienionych $w$ opisie Warszawy i jej okolic), mające zarówno charakter opisowy (wyjaśnienia, komentarze), jak i zawierające odsyłacze do innych partii pracy, ilustracje, system indeksów oraz plan Warszawy z 1850 roku (czyli tym razem z roku ukazania się książki).

Określenie „dodatek” użyte w tytule książki i przedmowie w odniesieniu do opisu Częstochowy należy rozumieć dosłownie. Ta część pracy Dubrowskiego jest bowiem dużo krótsza od opisu Warszawy, nie zostaje opatrzona indeksem, brakuje w niej wyszczególnienia źródeł informacji, podziału na rozdziały, choć dość wyraźnie zostają wyodrębnione segmenty tematyczne. Opis Częstochowy, a właściwie, jak czytamy w przedmowie, „częstochowskiego klasztoru, położonego w odległości 217 wiorst od Warszawy i połączonego z nią koleją żelazną"31, rozpoczyna się od nakreślenia topografii miasta i zarysu jego dziejów, sprzężonych z historią klasztoru na Jasnej Górze, aby zakończyć się charakterystyką klasztoru i obrazu Matki Boskiej. Czytelnik jakby zostaje oprowadzony ,za rękę” po poszczególnych pomieszczeniach klasztornych i na dłużej zatrzymuje się - wraz z osobą oprowadzającą - przed świętym wizerunkiem.

\section{Zakończenie}

Życiorysy Michaiła Glinki i przede wszystkim Piotra Dubrowskiego stanowią zaprzeczenie słów o ich ,rzuceniu w inny, daleki kraj”, pochodzących ze wspomnień Dubrowskiego o Glince i przytoczonych jako motto do niniejszego artykułu. Kilkakrotne, często wielomiesięczne pobyty na ziemiach polskich, wypełnione spotkaniami z ludźmi (przy czym nie tylko Polakami, ale i Rosjanami), oglądaniem miejsc i udziałem w życiu kulturalnym, przyczyniły się do „obrastania” przez nich wiedzą i przemyśleniami. „Inny, daleki kraj” dość szybko stał się bliski, znajomy i zrozumiały, a zatem dużo bardziej pasujące do sytuacji i stanu

${ }^{31}$ [П.П. Дубровский], Описание Вармавы..., c. nlb. (przedmowa). 
emocjonalnego obu twórców wydają się słowa o przyjeździe na ziemie polskie niż o „rzuceniu” na nie, sugerujące nagłość i przymusowość. Ów proces „obrastania” odbywał się bądź samoistnie, w sposób naturalny, jak w przypadku pobytu w każdym innym miejscu (wspomnienia Dubrowskiego o Glince), bądź stanowił świadome działanie, umiejętnie kierowane i zorientowane na określony cel (książka Dubrowskiego o Warszawie i Częstochowie). Co więcej, proces ten rozpoczynał się często przed przybyciem na ziemie polskie; „kontakty Glinki z kulturą polską, nawiązane na porankach muzycznych w petersburskim domu M. Szymanowskiej (1828-1829), a następnie podtrzymywane z K. Lipińskim (1838) i W. Każyńskim (1840-1841) w Petersburgu zostały wydatnie rozwinięte podczas prawie trzyletniego pobytu kompozytora w Warszawie" - pisze Adam Neuer ${ }^{32}$. Problem ten, a także bezpośrednio związana z nim kwestia rosyjskiej recepcji poezji Adama Mickiewicza i jej przekładu na język muzyki wydają się szczególnie ważne i perspektywiczne, na co wskazuje wydana w 2016 roku książka Grzegorza Wiśniewskiego o Igorze i Światosławie Bełzach, w której znajdujemy odtworzenie poglądów Igora Bełzy na, po pierwsze, proces wkraczania kompozytorów słowiańskich, przede wszystkim Fryderyka Chopina i Michaiła Glinki, na szczyty europejskiej kultury muzycznej, po drugie, problem paraleli między charakterem i wymową ich muzyki a wielką poezją romantyczną (,na przykład I Ballada [Chopina - M.D.] a Konradem Wallenrodem Mickiewicza"), po trzecie wreszcie, muzyczne interpretacje poezji Mickiewicza, nie tylko rosyjskie (,na przykład po Moja pieszczotkę sięgali i Alabjew, i Glinka, i Czajkowski, i Cui, i Rimski-Korsakow"), ale też zachodnioeuropejskie, znane przy tym w Rosji (,oparta na Konradzie Wallenrodzie opera Amilcare Ponchiellego Litwini z 1847 roku, wystawiona i w mediolańskiej La Scali, i w petersburskim Teatrze Maryjskim") $)^{33}$.

${ }^{32}$ A. Neuer, Glinka ..., s. 323.

${ }^{33}$ G. Wiśniewski, Między Polska i Rosja..., s. 46, 62, 82. Chodzi o balladę g-moll op. 23 Fryderyka Chopina. Jej związek z Konradem Wallenrodem uznawany jest jednak za kwestię dyskusyjną. 
Świadectwa pobytu Dubrowskiego i Glinki na ziemiach polskich w dużym stopniu są, jak inne przekazy, ,pochodną statusu społecznego autora wspomnień, powodów i celów jego przybycia, charakteru pobytu, rodzaju wykonywanych czynności, stopnia aklimatyzacji w nowym środowisku, sposobu akceptacji panujących w guberniach Królestwa Polskiego warunków [...], czasu przebywania na zachodnich rubieżach Cesarstwa Rosyjskiego", rzucając światło na niezwykle obszerny problem „charakteru i zakresu [...] relacji polsko-rosyjskich” w XIX wieku ${ }^{34}$.

\section{Bibliografia}

Bazylow L., Polacy w Petersburgu, Wrocław-Warszawa-Kraków-Gdańsk-Łódź 1984.

Bazylow L., Społeczeństwo rosyjskie w pierwszej połowie XIX wieku, WrocławWarszawa-Kraków-Gdańsk 1973.

Bełza I., Z dziejów polsko-rosyjskich kontaktów muzycznych, thum. S. Prus-Więckowski, E. Dziębowska, Kraków 1963.

Bibliografia literatury polskiej. Nowy Korbut, t. 4 (Oświecenie), red. E. Aleksandrowska, Warszawa 1966.

Jakóbiec M., Kluczowe problemy stosunków literackich polsko-rosyjskich w latach trzydziestych - czterdziestych wieku XIX, [w:] S. Fiszman (red.), Z polskich studiów slawistycznych. Prace historycznoliterackie na IV Międzynarodowy Kongres Slawistów w Moskwie 1958, Warszawa 1958, s. 12-143.

Kijas A., Polacy w Rosji od XVII wieku do 1917 roku. Stownik biograficzny, Warszawa-Poznań 2000.

Kucharska E., Działalność slawistyczna Piotra Dubrowskiego w świetle listów do Izmaiła Sriezniewskiego, Wrocław 1974.

Lipatow A., Europeizm: punkt wyjścia w poszukiwaniu porozumienia Polaków i Rosjan, [w:] M. Dąbrowska i P. Głuszkowski (red.), Nauka w Polsce i Rosji - miejsca wspólne, miejsca różne (obszar humanistyki), Warszawa 2016, s. $95-104$.

Mucha B., „Jutrzenka” 1842-1843, [w:] B. Galster, J. Kamionka-Straszakowa, K. Sierocka przy współudziale A. Piorunowej (red.), Zwierciadło prasy. Czasopisma polskie XIX wieku o literaturze rosyjskiej, Wrocław-Warszawa-Kraków-Gdańsk 1978, s. 133-147.

${ }^{34}$ S. Wiech, J. Legieć, Królestwo Polskie i jego mieszkańcy..., s. 15-16. 
Neuer A., Glinka, [w:] Encyklopedia muzyczna PWN, t. 3 (Część biograficzna. $E-F-G)$, Kraków 1987, s. 320-328.

Sulima R., Literatura a dialog kultur, Warszawa 1982.

Swolkień H., Michat Glinka, Warszawa 1984.

Wiech S., Legieć J., Królestwo Polskie i jego mieszkańcy w świetle rosyjskich wspomnień, pamiętników, relacji i dzienników. Zbiór bibliograficzny, Kielce 2015.

Wiśniewski G., Między Polska i Rosją - Igor i Swiatosław Belzowie, WarszawaPułtusk 2016.

Глинка М.И., Записки, ред. А.С. Розанов, Москва 1988.

Глинка в воспоминаниях современников, ред. А.А. Орлова, Москва 1955.

Глушковский П., Ф.В. Булгарин в русско-польских отношениях первой половины ХІХ века: эволюция идентичности и политических воззрений, Санкт-Петербург 2013.

Дубровский П., Воспоминания о М.И. Глинке. Письмо к Л.И. Шестаковой, „Русский вестник” 8(2)/1857, с. 571-580.

[Дубровский П.П.], Описание Варшавы и ее окрестностей с дополнением описания Ченстоховы. Составил П.Д. (С новейшим планом Варшавы), Варшава 1850.

Лихобабенко А.Е., Путеводители по Москве как тип справочного издания, [в:] М.М. Панфилов (ред.), Русская печать XIX-XX веков. Сборник статей, Москва 1994, с. 53-73.

Рейтблат А.И., Дубровский Петр Павлович, [в:] П.А. Николаев (ред.), Русские писатели 1800-1917. Биографический словарь, т. 2 (Г-К), Москва 1992, c. 192-193.

\section{Polish lands in the first half of the $19^{\text {th }}$ century in the eyes of the Russians (Peter Dubrovsky and Mikhail Glinka)}

The article presents the memories of P. I. Dubrovsky of M. I. Glinka ("Russkij vestnik"1857) and the Description of Warsaw and its vicinity... (Warsaw 1850; containing a description of Częstochowa, index of the streets and map of Warsaw) by P. I. Dubrovsky. Dubrovsky and Glinka stayed in the Polish lands in 1840's and 1850's. Peter Dubrovsky (1812-1882) was a literary scholar and linguist, author of the first book about Adam Mickiewicz, translator, editor of the periodical "Jutrzenka. Dennica" in Russian and Polish. Mikhail Glinka (1804-1857) was a composer of the operas Ivan Soussanine and Ruslan and Ludmila; in Warsaw he composed the orchestral scherzo Kamarinskaya.

Key words: Peter Dubrovsky, Mikhail Glinka, memories, Warsaw, contacts 